\title{
The Implementation of TPACK (Technology, Pedagogy, and Content Knowledge) Framework on Indonesian Online Mathematics Teachers Training
}

\author{
Rohmitawati \\ PPPPTK Matematika, Indonesia \\ rohmita@p4tkmatematika.org
}

\begin{abstract}
This study aimed to describe how the implementation of the TPACK (Technology, Pedagogy, and Content Knowledge) framework used for online mathematics teacher training, and to observe participants' response of the course. This research was a case study of online training for 30 Indonesian junior secondary school mathematics teachers on a quadrilateral course developed using the TPACK framework. The TPACK framework provides a map for understanding how to effectively integrate technology and instructional strategies into the content. The finding of this study for the teachers in the sample were: (1) The TPACK framework was implemented interactively in the integration process of GeoGebra (technology) using discovery learning strategies (pedagogy) on the square area formula (content) for quadrilateral properties; (2) The use of the TPACK framework on the online course received positive responses from teachers in the sample and they stated that it would be interesting and helpful when used in the classroom.
\end{abstract}

Keywords: TPACK, framework, quadrilateral, junior secondary school, mathematics teacher.

\section{Introduction}

Nowadays, technology develops so rapidly and many argue, that the use of technology can enhance effective learning.

Technology is essential in teaching and learning mathematics; it influences the mathematics that is taught and enhances students' learning (NCTM, 2000). Technology provides many opportunities to build students' conceptual knowledge about mathematics (Roblyer \& Doering, 2014, p. 334).

To use technology to support meaningful student learning, teachers need additional knowledge of the content they are required to teach, the pedagogical methods that facilitate student learning, and the specific ways in which technology can support those methods (Ertmer \& Leftwich, 2010, p. 260).

Mishra and Koehler (2006) stated that when teaching with technology integration, teachers should have a framework of knowledge called Technological Pedagogical Content Knowledge (TPACK). The TPACK framework for teacher knowledge is described in detail as a complex interaction among three bodies of knowledge; content, pedagogy, and technology (Koehler, Mishra, \& Cain, 2013).

The TPACK framework can help teachers describe the concepts to students; motivate students to learn mathematics; give students opportunities to experiment with mathematical concepts and skills; assess, evaluate, and provide feedback to student's work; and help them communicate mathematical solutions (Stoilescu, 2015). 
Based on the various descriptions above, teacher competencies which include content knowledge, pedagogy, and mastery of the use of technology in mathematics learning play an important role in learning success.

In Indonesia the use of ICT devices, especially computers in learning is still quite low at $6 \%$, which is still far below the international average, which is $37 \%$ (Puspendik Kemdikbud, 2016). Based on this, Indonesian teacher's ability to integrate technology in learning needs to be improved.

\section{Theoretical Background}

\section{TPACK Framework}

TPACK is an emergent form of knowledge that goes beyond all three "core" components (content, pedagogy, and technology). Technological pedagogical content knowledge is an understanding that emerged from the interaction among content pedagogy, and technology knowledge (Mishra and Koehler, 2006, p. 1028).

The TPACK framework for teacher knowledge produces the types of flexible knowledge needed to successfully integrate technology use into teaching (Koehler, Mishra, \& Chain, 2013). TPACK framework is illustrated as follows.

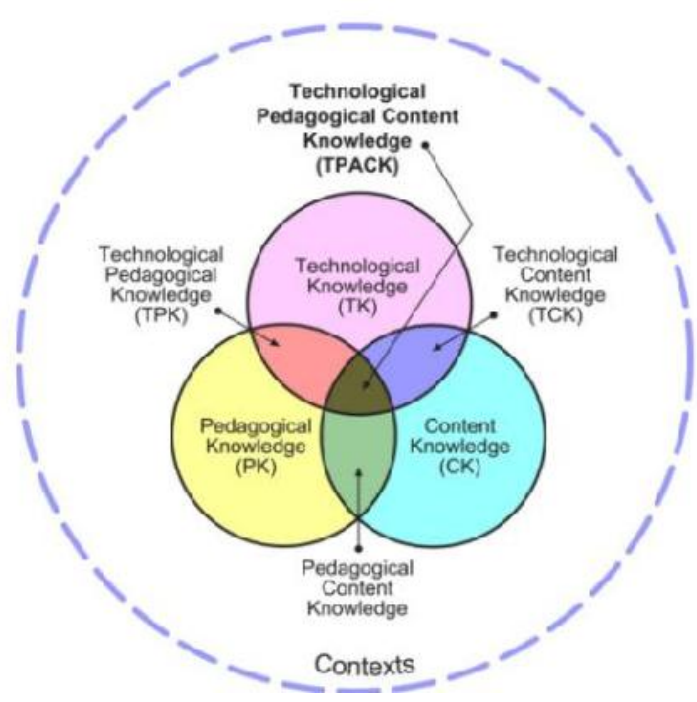

Figure 1. TPACK framework (Koehler, Mishra, \& Chain: 2013).

The figure shows that within the teaching context can be seen the intersection of the three main components of teachers' knowledge: content, pedagogy, and technology. These intersections represent the interactions between and among these bodies of knowledge, and in pairs are represented as PCK (pedagogical content knowledge), TCK (technological content knowledge), TPK (technological pedagogical knowledge), while the intersection area of all three is represented as TPACK.

Technology and content knowledge have a deep historical relationship. Content knowledge (CK) is teachers' knowledge about the subject matter to be learned or taught. Pedagogical Knowledge (PK) is teachers' deep knowledge about the processes and practices or methods of teaching and learning. Thus, PCK is the notion of the transformation of the subject matter for teaching. 
Technology Knowledge (TK) is the ways of thinking about, and working with technology and can apply to all technological tools and resources. Thus Technological Pedagogical Knowledge (TPK) is an understanding of how teaching and learning can change when particular technologies are used in particular ways. While TPACK is the intersection of TCK, PCK and TPK and represents teachers' knowledge of all three areas of content, technology and pedagogy.

Yurdakul, et al. (2013), stated that the training courses using the TPACK model were mostly given to inservice or preservice teachers. In general, teachers and/or preservice teachers were given TPACK training in the web environment or within the scope of a course. Generally, professional development programs had positive influence on teachers' TPACK development.

Therefore this study will examine the use of the TPACK framework with an online course involving the integration of technology (namely GeoGebra) and using discovery pedagogical strategies (discovery learning) to develop the teaching of quadrilateral properties with a sample of 30 Indonesian junior secondary school mathematics teachers.

\section{Methodology}

This research was a case study conducted with an online training for 30 Indonesian junior secondary school mathematics teachers working with a quadrilateral course developed using the TPACK framework. The data consisted of observations of the online training and the responses of the participants from a discussion forum and questionnaire.

\section{Results and Discussions}

The online training using the TPACK framework on the quadrilateral course which involved the definition of a quadrilateral and the analysis of the properties of a quadrilateral. In general, the instructional design of the learning objects are described as follows.

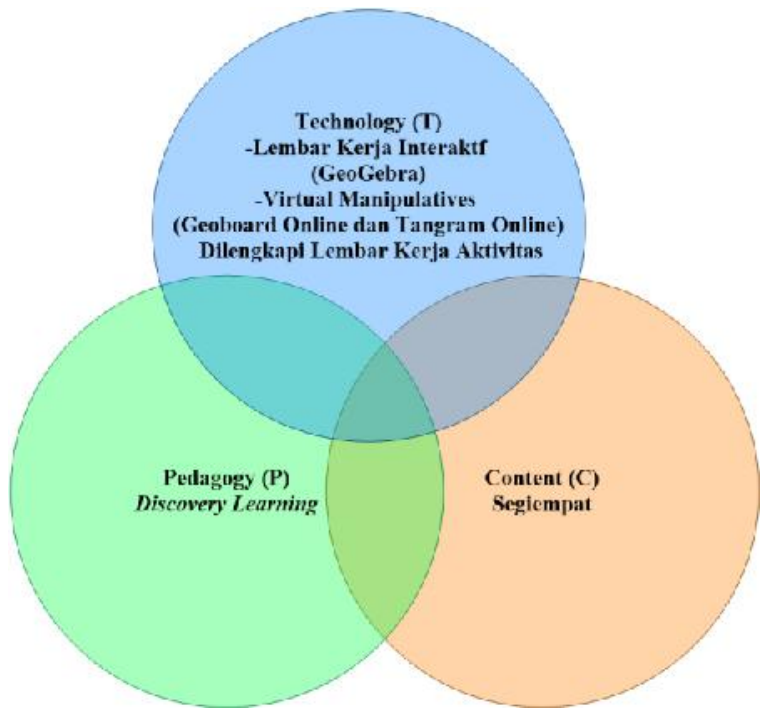

Figure 2. Design of implementation of TPACK framework. 
The TPACK framework was implemented using an online course that reflected the integration of various technologies such as GeoGebra, using a discovery learning pedagogical approach to the content area of quadrilateral properties and the quadrilateral broad formulas. The course also included the use of virtual manipulatives in the form of online tangram and online geoboard for a deeper understanding of quadrilateral concepts. Utilizing technology allowed interactivity to occur and the users constructed their own knowledge.

Table 1

An Example of Design Implementation of TPACK Framework

Framework TPACK

Content $(\mathrm{C})$

Pedagogy $(\mathrm{P})$

Technology (T)

Pedagogical Content

Knowledge (PCK)

Technological Content

Knowledge (TCK)

Technological

Pedagogical Knowledge

(TPK)

Technology, Pedagogy

and Content Knowledge (TPACK)

\section{Description}

Analysis of quadrilateral properties, area of quadrilateral.

Discovery learning.

GeoGebra.

Discovery learning, as a pedagogical strategy for investigating quadrilateral properties and the area of a quadrilateral.

Using GeoGebra for investigating quadrilateral properties and the area of a quadrilateral.

GeoGebra for facilitating discovery learning.

The discovery learning pedagogical strategy is based upon constructivist learning theory that requires active learning and emphasises students constructing their own knowledge so as to produce meaningful learning and to improve understanding of the material. Sunismi and Nu'Man's (2015) research of guided discovery learning using computer assisted geometry learning was reported as effective in strengthening and improving students' mathematical concepts.

The use of dynamic geometry software such as GeoGebra in mathematics learning showed positive results. GeoGebra has advantages such as being able to produce interactive worksheets that support constructive learning. 
Virtual manipulatives have been defined as an:

interactive, Web-based visual repre- sentation of a dynamic object that presents opportunities for constructing mathematical knowledge (Moyer, Bolyard \& Spikel, 2002, p. 1),

and are often modeled after concrete manipulatives.

Virtual manipulatives helped students to apply distinct representations of geometric transformations (Gulkilik, 2016, p. 213).

As well as the use of virtual geoboard and tangram manipulatives online for understanding concepts.

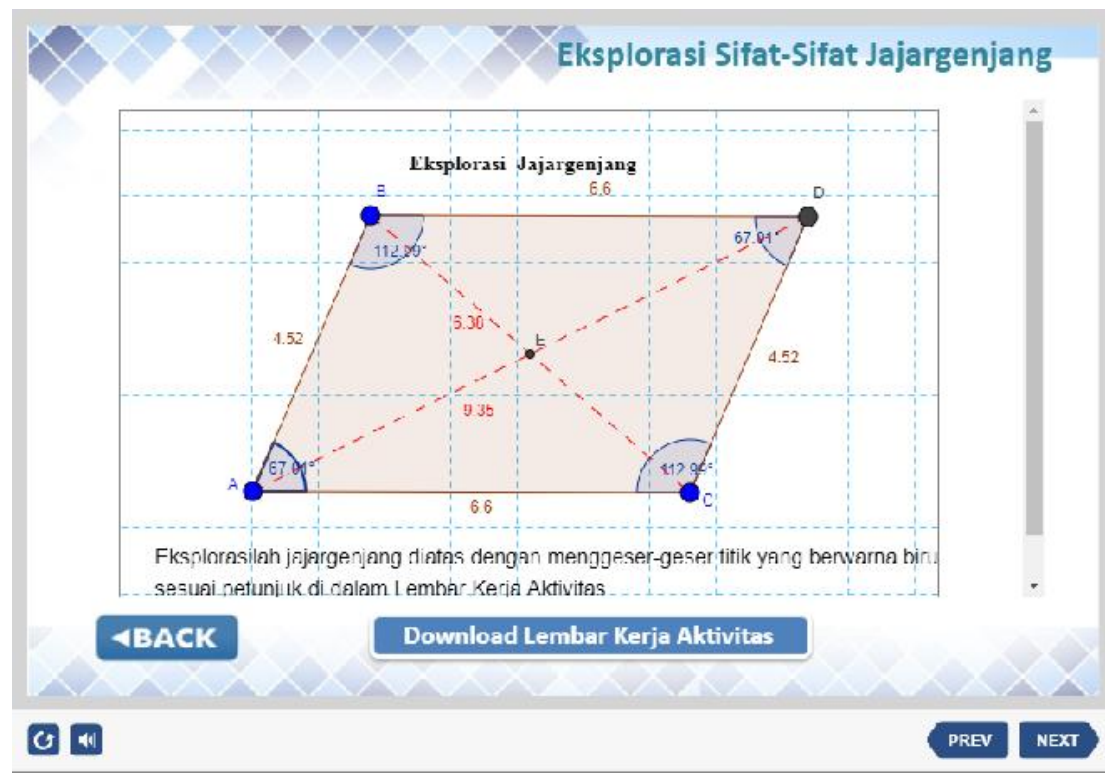

Figure 3. Interactive activity using GeoGebra to discover the quadrilateral properties.

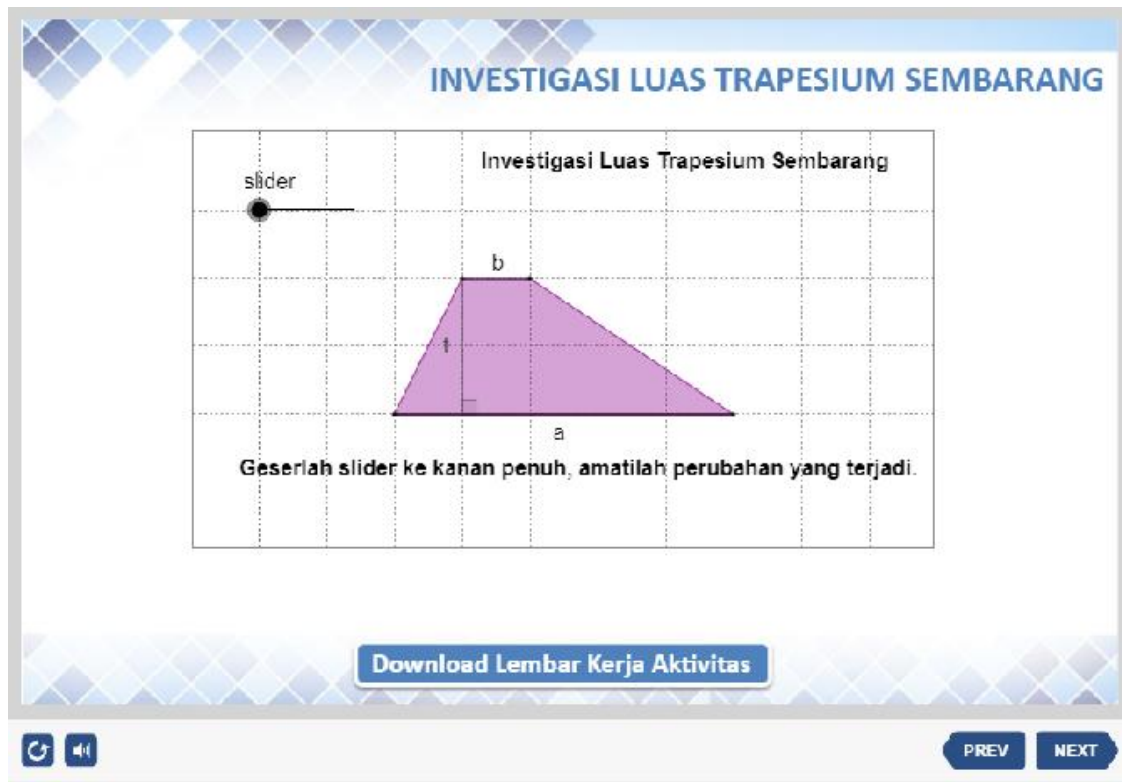

Figure 4. Interactive activity using GeoGebra to discover the area of a quadrilateral. 


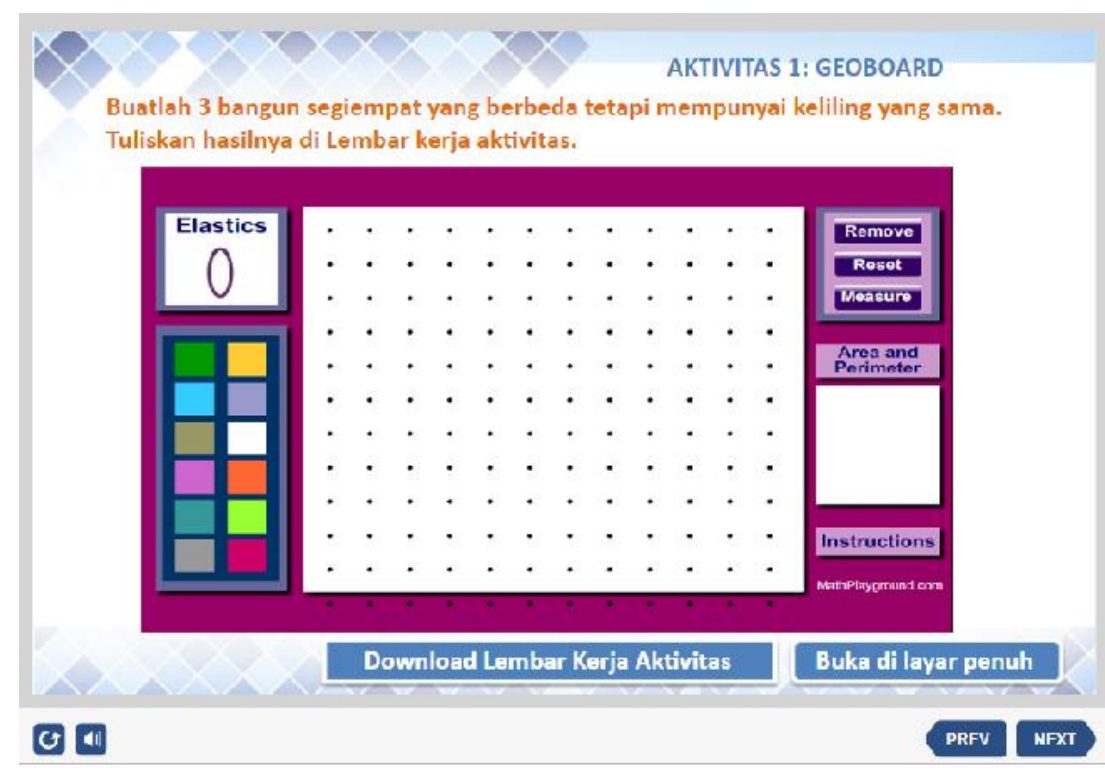

Figure 5. Interactive activity using the online virtual manipulative Geoboard for comprehension of quadrilateral perimeter.

\section{Teacher Responses}

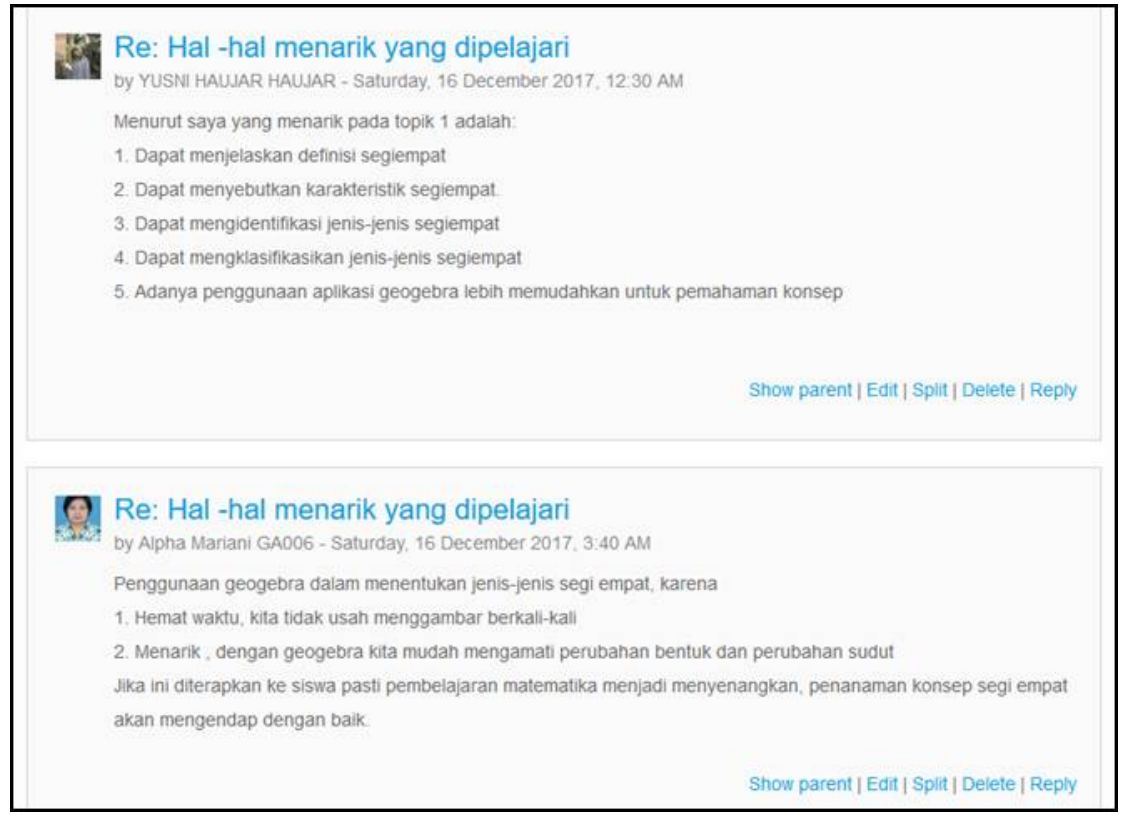

Figure 6. Sample of teacher responses.

The online training was using TPACK framework for the design, gave positive response from junior secondary school mathematics teachers. There were the results of observations of the learning process, some participant comments (code numbers show the 
serial number of participants) from the discussion forum and questionnaire are presented below:

I received a new concept new applications that can be used in the learning process of rectangles such as tangram, geoboard, and GeoGebra. (teacher14).

GeoGebra media is used for the analysis of quadrilateral properties. If this media is used as a student learning media, students' understanding of this topic will be better. That was interesnting (teacher17).

I feel interest when studying discovery area of quadrilateral using the GeoGebra, when it's applied in class, it will help students learn and be more interesting dan helpfull. (teacher13)

Looking around 3 rectangles that have the same parameter using Geoboard, this is very fun and challenging when applied in learning. (teacher12)

Very helpful for me how to implemented to teaching for my students. (teacher3).

\section{Conclusion}

The use of the TPACK framework in an online training course for Indonesian mathematics teacher involving the integration of technology with a discovery learning pedagogical strategy for the teaching of quadrilateral content received positive responses from the teachers. The teachers stated that it would be interesting and helpful when used in class.

Due to the sample limitations of this study, the findings can only apply to the teachers in the sample and cannot be regarded as representing a wider group of Indonesia teachers. However, the finding can be of interest to teachers and educators in making comparisons with their own situation.

In line with studies from other researchers (Yurdakul et al., 2013; Chai, Koh, \& Tsai, 2011; Harris \& Hofer, 2011) conducting teacher professional development training by applying TPACK models can give positive results. The TPACK Framework could act as guide to designing online training.

This was a small exploratory and descriptive study and further studies could measure the impact of online training when the teacher is implementing the TPACK framework in the classroom.

\section{References}

Chai, C. S., Koh, J. H. L., Tsai, C., \& Tan, L. L.W. (2011). Modelling primary school preservice teachers' Technological Pedagogical Content Knowledge (TPACK) for meaningful learning with information and communication technology (ICT). Computers \& Education, 57(1), 1184-1193. doi:10.1016/j.compedu.2011.01.007

Ertmer, P. A., \& Ottenbreit-Leftwich, A. T. (2010). Teacher technology change: How knowledge, confidence, beliefs, and culture intersect. Journal of Research on Technology in Education. https://doi.org/10.1080/15391523.2010.10782551 
Gulkilik, H. (2016). International perspectives on teaching and learning mathematics with virtual manipulatives (Vol. 7). https://doi.org/10.1007/978-3-319-32718-1

Harris, J. B., \& Hofer, M. J. (2011). Technological pedagogical content knowledge (TPACK) in action: A descriptive study of secondary teachers' curriculum-based, technologyrelated instructional planning. Journal of Research on Technology in Education, 43(3), 211-229.

Koehler, M. J., Mishra, P., \& Cain, W. (2013). What Is Technological Pedagogical Content Knowledge (TPACK)? Source: The Journal Of Education Pedagogical Content Knowledge, 193(3), 13-19. Retrieved from http://www.jstor.org/stable/24636917.

Mishra, P., \& Koehler, M. J. (2006). Technological pedagogical content knowledge: A framework for teacher knowledge. Teachers College Record, 108(6), 1017-1054. doi:10.1111/j.1467-9620.2006.00684.x

Moyer, S. P., Bolyard, J., \& Spikell, M. (2002). What are virtual manipulatives? Teaching Children Mathematics, 8(6), 372-377. https://doi.org/http://dx.doi.org/10.1108/17506200710779521

NCTM. (2000). Principles and Standards for School Mathematics. Reston, VA: Author.

Puspendik. Badan Penelitian dan Pengembangan. Kemendikbud. (2016). Mengenai TIMSS. Retrieved from http://puspendik.kemdikbud.go.id/seminar/upload/Hasil\%20Seminar\%20 Puspendik\%202016/TIMSS\%20infographic.pdf.

Roblyer \& Doering. (2014). Integrating educational technology into teaching. Boston: Pearson New International.

Stoilescu, D. (2015). A critical examination of the technological pedagogical content knowledge framework: secondary school mathematics teachers integrating technology. Journal of Educational Computing Research. https://doi.org/10.1177/0735633115572285

Sunismi \& Nu'Man Mulin. (2013). Pengembangan bahan pembelajaran geometri dan pengukuran model penemuan terbimbing berbantuan komputer untuk memperkuat konsepsi siswa. Jurnal Cakrawala Pendidikan, XXXI(2), 200 - 216. doi: 10.21831/cp.v5i2.1557

Yurdakul, I. K., Odabasi, H. F., Sahin, Y. L., \& Coklar, A. N. (2013). A TPACK course for developing pre-service teachers' technology integration competencies: from design and application to evaluation. Research Perspectives and Best Practices in Educational Technology Integration, 242-269. https://doi.org/10.4018/978-1-4666-2988-2 